We are indebted to the volunteers in this study. CG is supported by the Foundation of 1870 .

1 Acheson ED. AIDS: a challenge for the public health. Lancet 1986;i:662-6.

2 Van de Perre P, Clumeck N, Carael M, et al. Female prostitutes: a risk group for infection with human T-cell lymphotropic virus type III. Lancet 1985;ii:524-6.

3 Kreiss JK, Koech D, Plummer FA, et al. AIDS virus infection in Nairobi prostitutes. N Englf M Med 1986;314:414-8

4 Barton SE, Underhill GS, Gilchrist C, et al. HTLV-III antibody in prostitutes. Lancet 1985; ;i: 1424.

5 Petersen CS, Wantzin GL, Gerstoft J, et al. Occurrence of antibody to human T-cell leukemia

lymphovirus type III (LAV/HTLV-III) in the venereological clientele in Copenhagen. Ugeskr Laeger 1986;148:821-2.

(Accepted 15 September 1986

Department of Medicine, Divisions of Hepatology and Infectious Diseases, Hvidovre Hospital, University of Copenhagen, 2650 Hvidovre, Denmark

KIM KROGSGAARD, MD, research fellow

CHRISTIAN GLUUD, MD, senior registrar

COURT PEDERSEN, MD, research fellow

JENS OLE NIELSEN, MD, senior consultant

ERIK JUHL, MD, senior consultant

Rubella and Enterovirus Departments, State Serum Institute, Copenhagen, Denmark

JAN GERSTOFT, $M D$, registrar

CARSTEN MØLLER NIELSEN, MD, registrar

Correspondence to: Dr Gluud, Department of Medical Gastroenterology, Herlev University Hospital, DK 2730 Herlev, Denmark.

\section{Red cell antibodies and autoimmune haemolysis after treatment with azapropazone}

Non-steroidal anti-inflammatory drugs are prescribed widely to the eight million people who consult their general practitioners every year with rheumatic complaints. Haematological side effects are well recognised as anaemia related to gastrointestinal blood loss, aplastic anaemia and agranulocytosis in association with phenylbutazone, ${ }^{1}$ and autoimmune haemolysis in relation to treatment with mefenamic acid. ${ }^{2}$ Autoimmune haemolysis has also been reported in association with ibuprofen ${ }^{3}$ and naproxen. ${ }^{4}$

Azapropazone, a relatively new pyrazolon, is structurally similar to phenylbutazone but is not associated with blood disorders other than anaemia due to gastrointestinal blood loss. ${ }^{1}$ We report on four patients with positive direct antiglobulin test results, of whom two showed frank haemolysis after treatment with azapropazone.

\section{Case report}

Case 1-A 74 year old woman presented with anaemia. She had osteoarthritis and had been taking azapropazone for four years. Results of laboratory investigations were: haemoglobin concentration $74 \mathrm{~g} / 1$, white cell count $6 \times 10^{9} / 1$, platelet count $267 \times 10^{9} / 1$, reticulocytes $18 \%$, and erythrocyte sedimentation rate $100 \mathrm{~mm}$ in first hour. Spherocytes were seen in the blood film. Bilirubin concentration was $79 \mu \mathrm{mol} / 1(4.6 \mathrm{mg} / 100 \mathrm{ml})$ (unconjugated $60 \mu \mathrm{mol} / 1 ; 3.5 \mathrm{mg}$ / $100 \mathrm{ml}$ ) and lactate dehydrogenase activity $1333 \mathrm{U} / 1$ (normal $240-525 \mathrm{U} / \mathrm{l}$ ). The direct antiglobulin test result was positive with an IgG coating only. Free antibodies were found in the serum, but no red cell specificity was identified. Antinuclear factor was detected at $1 / 256$, but tests for deoxyribonucleic acid antibodies and rheumatoid factor gave negative results. Azapropazone was stopped and prednisolone $60 \mathrm{mg}$ daily instituted. The haemoglobin concentration started to rise at day 7 , and prednisolone was stopped. On day 21 the haemoglobin concentration was $122 \mathrm{~g} / \mathrm{l}$ and the reticulocyte count $3 \%$. At six months haemoglobin was $143 \mathrm{~g} / \mathrm{l}$ with the direct antiglobulin test still giving a strongly positive result.

Case 2-A 73 year old woman was referred to the haematology clinic with anaemia. She had osteoarthritis and had been taking azapropazone for 18 months. A direct antiglobulin test had given a negative result four years previously. Haemoglobin concentration was $108 \mathrm{~g} / \mathrm{l}$ and reticulocyte count $7 \%$, and spherocytes were noted in the blood film. The direct antiglobulin test was positive with an IgG and IgM coating without complement. Free anti-e was detected in the serum ( $R$ h genotype $\mathrm{R}_{1} \mathrm{r} \mathrm{CDe} / \mathrm{cde}$ ). Azapropazone was stopped. The result of the direct antiglobulin test remained positive at six weeks, but the haemoglobin concentration had risen to $132 \mathrm{~g} / 1$.

We performed the direct antiglobulin test on a further eight patients taking azapropazone. These eight patients were selected at random. Four were identified by the pharmacy department as hospital inpatients taking azapropazone, three were identified by information on the blood count report form completed by their general practitioners, and one was attending the haematology department. In two patients the test result was positive with no evidence of haemolysis.

Case 3-A 71 year old woman who had been taking azapropazone for two years yielded a positive direct antiglobulin test result with an IgG coating. Complement coating was not present and there was no evidence of haemolysis. The drug was stopped and a month later the test result was negative.

Case 4-A 68 year old man with a three year history of chronic myelomonocytic leukaemia was given azapropazone by his general practitioner because of joint pains. His direct antiglobulin test result had been negative six months previously. The result became positive with an IgG coating within three months of starting treatment. Azapropazone was stopped but at one month the test result remained positive.

The other six patients had negative direct antiglobulin test results. No history was available for three of these patients, in whom the duration of treatment with azapropazone was unknown. The other three patients had been taking azapropazone for more than one year.

\section{Comment}

The Committee on the Safety of Medicines has been notified of six cases of Coombs positive haemolytic anaemia with azapropazone between January 1984 and March 1985, and the manufacturers of the drug have had reports of six cases of autoimmune haemolysis over 10 years. Our four cases strongly implicate azapropazone as the causal agent for the development of red cell autoantibodies, which in one instance was shown to have anti-e specificity. If the eight patients selected at random in this limited study were representative of all patients taking azapropazone then a quarter may be expected to develop a positive direct antiglobulin test result. This proportion is similar to that found with methyldopa ${ }^{5}$ but cannot be used to predict the incidence of autoimmune haemolysis.

1 Joint Formulary Committee. Musculoskeletal and joint diseases. British National Formulary. No 11. London: British Medical Association and Pharmaceutical Society of Great Britain, 1986 312-9.

2 Scott GL, Myles AB, Bacon PA. Autoimmune haemolytic anaemia and mefenamic acid therapy. BrMed f 1968;iii:534-5.

3 Guidry JB, Ogburn CL, Griffin FM. Fatal autoimmune hemolytic anemia associated with ibuprofen. FAMA 1979;242:68-9.

+ Lo TCH, Martin MA. Autoimmune haemolytic anaemia associated with naproxen suppositories. Br.Med F 1986;292:1430.

5 Petz L. Drug-induced immune haemolytic anaemia. Clin Haematol 1980;9(3):455-81.

(Accepted 18 September 1986)

Departments of Haematology and Pharmacy, Monklands District General Hospital, Airdrie ML6 0JS

D CHAN-LAM, MB, CHB, senior house officer

A W THORBURN, MSC, MPS, staff pharmacist

E A CHALMERS, MB, CHB, senior house officer

W H WATSON, MRCP, MRCPATH, consultant

E J FITZSIMONS, MRCP, MRCPATH, consultant

Correspondence to: Dr Chan-Lam.

\section{Phaeochromocytoma in the elderly: a poorly recognised entity?}

Phaeochromocytoma is an uncommon disease in the elderly, with less than $3 \%$ of reported cases occurring in patients over 70 years of age. ${ }^{1}$ Malignant phaeochromocytoma has been described in this age group in only one postmortem case report 30 years ago. ${ }^{2}$ We report on four elderly patients with phaeochromocytoma seen over a year, two of whom had malignant tumours.

\section{Case reports}

Case 1-A 74 year old woman with a five year history of mild hypertension presented with nausea and vomiting. Severe labile hypertension was noted after treatment with $\beta$ blockers was started. Urinary adrenaline and dopamine concentrations were considerably raised, and computed tomography showed a left sided adrenal mass. At operation a $12 \mathrm{~cm}$ tumour was found with local venous invasion. Postoperatively she suffered persistent hypertension and raised excretion of urinary catecholamines, and an iodine-131-metaiodobenzylguanidine scan showed multiple skeletal metastases. Over the following months she became progressively more cachectic and died.

Case 2-A 72 year old woman with neurofibromatosis and a 15 year history of mild hypertension underwent computed tomography of the abdomen for investigation of an abdominal mass, which showed a pancreatic cyst and a left sided adrenal mass. Urinary adrenaline concentrations were slightly raised. Six months later, during surgery for removal of a sigmoid carcinoma, she developed 